\title{
EFEKTIVITAS BERMAIN KULIT JERUK BALI TERHADAP PERKEMBANGAN KREATIVITAS ANAK DI TAMAN KANAK-KANAK KASIH IBU PASAMAN TIMUR
}

\author{
Sepgita Asri \\ sepgitaasri4@gmail.com
}

Rivda Yetti

Asdi Wirman

\begin{abstract}
Penelitian ini bertujuan untuk mengetahui seberapa efektif bermain kulit jeruk bali terhadap perkembangan kreativitas anak di Taman Kanak-kanak Kasih Ibu Pasaman Timur. Penelitian ini menggunakan pendekatan Kuantitatif yang berbentuk Quashi Exsperiment. Teknik pengumpulan data menggunakan tes, berupa pernyataan sebanyak 4 butir pernyataan dan teknik analisis data menggunakan uji normalitas, uji homogenitas, uji hipotesis, alat pengumpul data digunakan lembaran pernyataan. Kemudian data diolah dengan uji perbedaan (t-test). Berdasarkan analisis data, diperoleh rata-rata hasil tes kelompok eksperimen adalah 88,12dan SD sebesar 5,89 sedangkan pada kelompok kontrol adalah 81,87dan SD sebesar 4,38. Pada pengujian hipotesis diperoleh thitung sebesar 2,561dan tabel sebesar 2,07387pada taraf nyata $\alpha=0,05$ dan $d k=18$. Pada uji effectsize =1,27 yang dinyatakan tinggi. Maka dapat disimpulkan bahwa bermain kulit jeruk bali efektif terhadap perkembangan kreativitas di Taman Kanak-kanak Kasih Ibu Pasaman Timur.
\end{abstract}

Keywords: Bermain Kulit Jeruk Bali; Perkembangan Kreativitas

\section{PENDAHULUAN}

Jeruk bali ( Citrus grandis L ) merupakan jenis tanaman jeruk dengan ukuran yang lebih besar dibandingkan dengan jeruk biasa yang kita temui dipasar. Jeruk bali dapat tumbuh subur di dataran rendah maupun dataran tinggi. Tanamn ini tersebar di Sumatera, Jawaa, Bali, Sulawesi dan Kalimantan. Menurut Husna (2009: 20) menyatakan jeruk bali adalah jeruk sebesar buah melon dan berkulit tebal. Kulitnya dapat dimanfaatkan kembali untuk dibuat mobil-mobilan sederhana. Kulit jeruk tidak asing lagi untuk anak, tetapi anak tidak mengetahui kalau kulit jeruk dapat digunakan untuk bermain. Terutama dalam mengembangkan kreativitas anak, dengan bermain kulit jeruk anak dapat bekreasi sesuai dengan idenya sendiri.

Menurut Rukmana (2002: 9) menyatakan salah satu limbah yang dapat diolah dalam skala industri rumah tangga adalah limbah kulit jeruk besar. Limbah kulit jeruk besar biasanya dibuang ketempat sampah atau dibuat mainan anak-anak. kulit jeruk dapat diolah menjadi produk baru. Sudarma (2013: 17) kreativitas adalah sebuah keterampilan hidup (life skill) yang mampu melahirkan ide atau gagasan baru. Mahyudin ( 2007 : 3 ) Kreativitas berarti 
kemampuan menghasilkan sesuatu yang baru dan orisinal yang berwujud ide-ide dan alat-alat, serta lebih spesifik lagi, keahlian untuk menemukan sesuatu yang baru (inventiveness).

Berdasarkan pengertian di atas dapat disimpulkan kemampuan kreativitas dapat dikembangkan melalui kegiatan bermain kulit jeruk bali. Melalui kegiatan bermain kulit jeruk bali anak dapat menciptakan bentuk potongan, menyusun potongan dan anak juga bisa menghiasai bentuk yang telah dibuat dengan mencatnya, sehingga kemampuan kreativitas anak bisa berkembang dengan baik. Kulit jeruk bali merupakan media yang menarik, aman dan tidak asing lagi bagi anak.

Berdasarkan pengamatan peneliti di Taman Kanak-kanak Kasih Ibu Pasaman Timur, peneliti menemukan kreativitas anak kurang berkembang optimal,hal ini terlihat dari kurangnya imajinasi dan ide-ide kreatif dari anak dalam membentuk dan mengeksplorasikan sebuah karya dan terlihat hasil karya anak hampir sama dengan contoh yang diberikan guru baik dari segi bentuk maupun warna. Media yang digunakan anak juga kurang bervariasi. Sementara itu banyak media pembelajaran yang ada di sekitar anak yang bisa dimanfaatkan contohnya media dari bahan alam. Dengan demikian terlihat bahwa masih terdapat beberapa anak yang perkembangan kreativitas belum berkembang sesuai tahap perkembangannya.

Dilihat dari permasalahan diatas perlu adanya suatu upaya perubahan yang harus dilakukan guru dalam perkembangan kreativitas pada anak di Taman Kanakkanak Kasih Ibu Pasaman Timur. Untuk mengembangkan kreativitas pada anak, ada satu permainan yang dapat mengembangkan kreativitas anak yaitu bermain dengan kulit jeruk. Jeruk yang digunakan adalah jeruk bali. Jeruk bali adalah jeruk sebesar buah melon dan berkulit tebal. Kulitnya bisa dimanfaatkan untuk belajar sambil bermain. Bermain dengan kulit jeruk bisa meningkatkan kemampuan berfikir kreatif. Bukan itu saja, tetapi bisa mengembangkan keterampilan motorik kasar dan motorik halus anak dalam membuat karya-karya kreatif.

Bermain dengan kulit jeruk akan membuat anak merasa senang dan tidak merasa jenuh dalam proses kegiatan belajar. Dalam bermain kulit jeruk guru terlebih dahulu membagikan kulit jeruk kepada anak, kemudian anak membentuk kulit jeruk menggunakan gunting sesuai dengan apa yang diinginkan anak. Anak bisa membuat bentuk apapun yang mereka suka atau inginkan, misalnya anak membentuk lingkaran, membuat bentuk orang, tusuk sate, mobil-mobilan, kapal dan lain sebagainya.

Setelah kulit jeruk dibentuk oleh anak sesuai dengan yang diinginkannya, anak juga bisa memberikan warna pada kulit jeruk yang telah dibuat. Bahan yang digunakan untuk memberikan warna pada kulit jeruk adalah cat poster. Anak bebas memberikan warna sesuai dengan idenya. Kulit jeruk yang telah diberi warna akan terlihat lebih menarik, karena pada saat anak memberi warna anak bisa mengkombinasikan warna-warna yang diinginkannya.

Berdasarkan latar belakang diatas, maka peneliti tertarik untuk melakukan penelitian dengan judul "Efektivitas Bermain Kulit Jeruk Bali Terhadap Perkembangan Kreativitas Anak Di Taman Kanak-kanak Kasih Ibu Pasaman Timur".

\section{METODE PENELITIAN}

Jenis penelitian ini adalah kuantitatif dengan metode eksperimen dalam bentuk Quasi experimental (eksperimen semu), Sugiyono (2014:72) mengemukakan metode eksperimen adalah metode penelitian yang digunakan untuk mencari pengaruh perlakuan tertentu terhadap yang lain dalam kondisi yang terkendalikan. 
Populasi dalam penelitian ini adalah Taman Kanak-kanak Kasih Ibu yang memiliki 45 jumlah anak yang terbagi kedalam lima kelompok belajar. Teknik pengambilan sampel yang dilakukan dalam penelitian adalah teknik purposive sampling. Sampel dalam penelitian ini adalah kelompok B2 dan B3. Dimana kelompok B2 dijadikan kelompok eksperimen dan kelompok B3 dijadikan kelompok kontrol dengan pertimbangan jumlah anak kedua kelompok sama yaitu masing-masing 10 anak, usia yang sama, tingkat kemampuan anak yang sama, fasilitas belajar yang sama, latar belakang kemampuan guru yang sama, dan rekomendasi dari guru kedua kelompok serta Kepala Sekolah Taman Kanak-kanak Kasih Ibu Pasaman.

Variabel Penelitian adalah suatu atribut atau sifat atau nilai dari orang, obyek atau kegiatan yang mempunyai variasi tertentu yang ditetapkan oleh peneliti untuk dipelajari dan kemudian ditarik kesimpulannya. Adapun yang menjadi variabel dalam penelitian ini adalah variabel bebas dan variabel terikat. Variabel bebas merupakan variabel yang mempengaruhi atau menjadi sebab perubahan atau timbulnya variabel terikat. Variabel bebas dalam penelitian ini adalah bermain kulit jeruk bali. Variabel terikat merupakan variabel yang dipengaruhi atau menjadi akibat, karena adanya variabel bebas. Variabel terikat dalam penelitian ini adalah kemampuan kreativitas.

Arikunto (2010:172) menjelaskan bahwa sumber data dalam penelitian adalah sumber dari mana data diperoleh. Sumber data dalam penelitian ini adalah anak usia dini yang terpilih sebagai sampel penelitian yaitu $B_{2}$ sebagai kelompok eksperimen dan $B_{3}$ sebagai kelompok kontrol. Dalam penelitian ini penulis menggunakan tes buatan guru yang disusun dalam bentuk tes perbuatan.

Teknik analisis data yang digunakan dalam penelitian ini adalah membandingkan perbedaan dari dua ratarata nilai, sehingga dilakukan dengan uji $T$ (t-test). Namun sebelum itu terlebih dahulu melakukan uji normalitas dan homogenitas. Uji normalitas bertujuan melihat apakah data berdistribusi normal atau tidak. Uji normalitas dilakukan sebelum mengolah data dengan teknik korelasi product moment, regresi, t-tes, dan anava dan sebagainya. Uji homogenitas bertujuan untuk mengetahui apakah data kelas sampel dalam penelitian ini sudah berasal dari populasi yang homogen. Untuk menguji homogenitas dilakukan uji Bartlett dan effectsize berdasarkan uji Cohen's.

\section{HASIL DAN PEMBAHASAN Hasil}

Untuk menarik kesimpulan dari hasil penelitian, dilakukan uji hipotesis dengan menggunakan uji t. Sebelum melakukan uji t terlebih dahulu dilakukan uji normalitas dan uji homogenitas terhadap hasil penelitian. Berdasarkan hasil penelitian yaitu perkembangan kemampuan kreativitas pada kelompok eksperimen dan kelompok kontrol, diperoleh hasil bahwa perkembangan kemampuan kreativitas anak di kelompok eksperimen (kelompok B2) lebih tinggi dibandingkan pada kelas kontrol (kelompok B3).

Berdasarkan uji normalitas kelompok eksperimen dan kelompok kontrol diperoleh harga $L_{o}$ dan $L_{t}$ pada taraf nyata 0,05 untuk $\mathrm{N}=10$. Kelompok eksperimen nilai $L_{\text {hitung }} \mathbf{0 , 1 3 8 2}$ lebih kecil dari $L_{\text {tabel }} \mathbf{0 , 2 5 8}$ untuk $\alpha$ 0,05. Dengan demikian nilai kelompok eksperimen berasal dari data yang berdistribusi normal. Sedangkan kelompok kontrol diperoleh $L_{\text {hitung }} \mathbf{0 , 2 0 2 6}$ lebih kecil dari $L_{\text {tabel }} \mathbf{0 , 2 5 8}$ untuk $\alpha_{0,05}$. Ini berarti bahwa data kelompok kontrol berasal dari data yang berdistribusi normal.

Pengujian ini bertujuan untuk mengetahui apakah data berasal dari kelompok yang homogen, antara kelompok eksperimen dan kelompok kontrol. Jika chi 
kuadrat hitung <chi kuadrat tabel berarti data berasal dari kelompok yang homogen. Hasil perhitungan diperoleh $\chi^{2}$ hitung sebesar 1,6578, $\chi_{\text {hitung kelompok eksperimen dan }}^{2}$ kelompok kontrol lebih kecil dari $\chi^{2}$ tabel ( $\chi_{\text {hitung }}^{2}<\chi_{\text {tabel), }}^{2}$ berarti kelompok eksperimen dan kelompok kontrol memiliki varians yang homogen.

mengetahui apakah terdapat perbedaan yang signifikan untuk kedua kelompok. Apabila

$\boldsymbol{t}$ hitung $<\boldsymbol{t}_{\text {tabel }}$ berarati tidak terdapat perbedaan yang signifikan antara kedua kelompok.

Untuk menguji hipotesis digunakan ttest. Dari hasil uji hipotesis dengan menggunakan t-test diperoleh hasil $\mathbf{t}_{\text {hitung }}$ lebih kecil dari pada $\mathbf{t}_{\text {tabel }}(\mathbf{1}, \mathbf{1 2 6}<\mathbf{2 , 1 0 0 9 2 )}$. Dengan dk $\left(\mathrm{N}_{1}-1\right)+\left(\mathrm{N}_{2}-1\right)=18$. Dalam tabel df untuk taraf nyata $\alpha=0,05$ (5\%) didapat harga $t_{\text {tabel }}=\mathbf{2 , 1 0 0 9 2}$ maka dapat dikatakan bahwa hipotesis $\mathrm{H}_{\mathrm{a}}$ ditolak atau $\mathrm{H}_{\mathrm{o}}$ diterima. Dapat disimpulkan bahwa tidak terdapat perbedaan yang signifikan antara hasil pretest (kemampuan awal) anak di kelompok eksperimen dan kelompok kontrol dalam perkembangan kreativitas anak.

Data post-test penelitian kelompok eksperimen dan kelompok kontrol diolah untuk menentukan uji normalitas. Pada uji normalitas ini digunakan uji Liliefors Untuk kelompok kontrol diperoleh $L_{\text {hitung }} \mathbf{0 , 1 7 1 1}$ lebih kecil dari $L_{\text {tabel }} \mathbf{0 , 2 5 8}$ untuk $\alpha=0,05$. Ini berarti bahwa data kelompok kontrol berasal dari data yang berdistribusi normal.

Pengujian persyaratan yang kedua adalah pengujian homogenitas dengan menggunakan uji Barlett. Pengujian ini bertujuan untuk mengetahui apakah data berasal dari kelompok yang homogen, antara kelompok eksperimen dan kelompok kontrol. Jika chi kuadrat hitung < chi kuadrat tabel berarti data berasal dari kelompok yang homogen. Hasil perhitungan

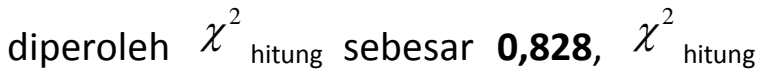

kelompok eksperimen dan kelompok kontrol lebih kecil dari $\chi_{\text {tabel }}^{2} \chi_{\text {hitung }}^{2} \chi^{2}$ tabel), berarti kelompok eksperimen dan kelompok kontrol memiliki varians yang homogen.

Setelah dilakukan uji normalitas dan uji homogenitas, diketahui bahwa kedua kelompok sampel berdistribusi normal dan mempunyai varians homogen. Maka dapat dilanjutkan dengan pengujian hipotesis dengan menggunakan teknik t-test, untuk mengetahui apakah terdapat perbedaan yang signifikan untuk kedua kelompok. Apabila $\boldsymbol{t}_{\text {hitung }}>\boldsymbol{t}$ tabel berarti terdapat perbedaan yang signifikan antara kedua kelompok.

Untuk menguji hipotesis digunakan ttest. Dari hasil uji hipotesis dengan menggunakan t-test diperoleh hasil $\mathbf{t}_{\text {hitung }}$ lebih besar dari pada $t_{\text {tabel }}(\mathbf{2 , 5 6 1}$ $>2,10092)$. Dengan dk $\left(N_{1}-1\right)+\left(N_{2}-1\right)=18$. Dalam tabel df untuk taraf nyata $\alpha=0,05$ (5\%) didapat harga $t_{\text {tabel }}=\mathbf{2 , 1 0 0 9 2}$ maka dapat dikatakan bahwa hipotesis $H_{a}$ diterima atau $\mathrm{H}_{\mathrm{o}}$ ditolak. Dapat disimpulkan bahwa terdapat perbedaan yang signifikan antara hasil post-test (kemampuan akhir) anak di kelompok eksperimen dan kelompok kontrol dalam perkembangan kreativitas anak.

Setelah dilakukan perhitungan nilai pre-test dan post-test kelompok eksperimen dan kontrol maka selanjutnya akan dilakukan perbandingan antara nilai pre-test dan nilai post-test, yang tujuannya untuk melihat apakah ada perbedaan nilai pre-test dan nilai post-test anak.

Tabel 1. Perbandingan Hasil Perhitungan Nilai Pre-test dan Post-Test

\begin{tabular}{lcccc}
\hline Variabel & \multicolumn{2}{c}{ Pre-test } & \multicolumn{2}{c}{ Post-test } \\
\cline { 2 - 5 } & $\begin{array}{c}\text { Ekspe } \\
\text { rimen }\end{array}$ & Kontrol & $\begin{array}{c}\text { Ekspe } \\
\text { rimen }\end{array}$ & Kontrol \\
\hline $\begin{array}{l}\text { Nilai } \\
\text { tertinggi }\end{array}$ & 75 & 68,75 & 93,75 & 87,5 \\
\hline $\begin{array}{l}\text { Nilai } \\
\text { terendah }\end{array}$ & 56,25 & 56,25 & 75 & 75 \\
\hline Rata-rata & 66,87 & 63,75 & 88,12 & 81,87 \\
\hline
\end{tabular}


Berdasarkan tabel 1 di atas, terlihat perbandingan hasil perhitungan nilai pretest dan nilai post-test. Pada pre-test nilai tertinggi yang diperoleh anak kelas eksperimen yaitu 75 dan nilai terendah 56,25 , dengan rata-rata 66,87 sedangkan pada kelas kontrol nilai tertinggi yang diperoleh anak yaitu 63,75 dan nilai terendah 56,25 dengan rata-rata 63,75. Pada post-test nilai tertinggi yang diperoleh anak kelas eksperimen yaitu 93,75 dan nilai terendah 75 dengan rata-rata 88,12 sedangkan pada kelas kontrol post-test nilai tertinggi yang diperoleh anak yaitu 87,5 dan nilai terendah 75 dengan rata-rata 81,87 .

Perbandingan hasil perhitungan nilai pre-test dan post test terlihat pada nilai tertinggi dan nilai terendah yang diperoleh anak dan terlihat pada rata-rata kelas eksperimen dan kelas kontrol pada posttest dimana pada post-test rata-rata menjadi lebih efektif dari rata-rata pre-test setelah dilakukan treatment. Agar lebih jelasnya bisa dilihat dalam grafik di gambar 1 berikut ini.

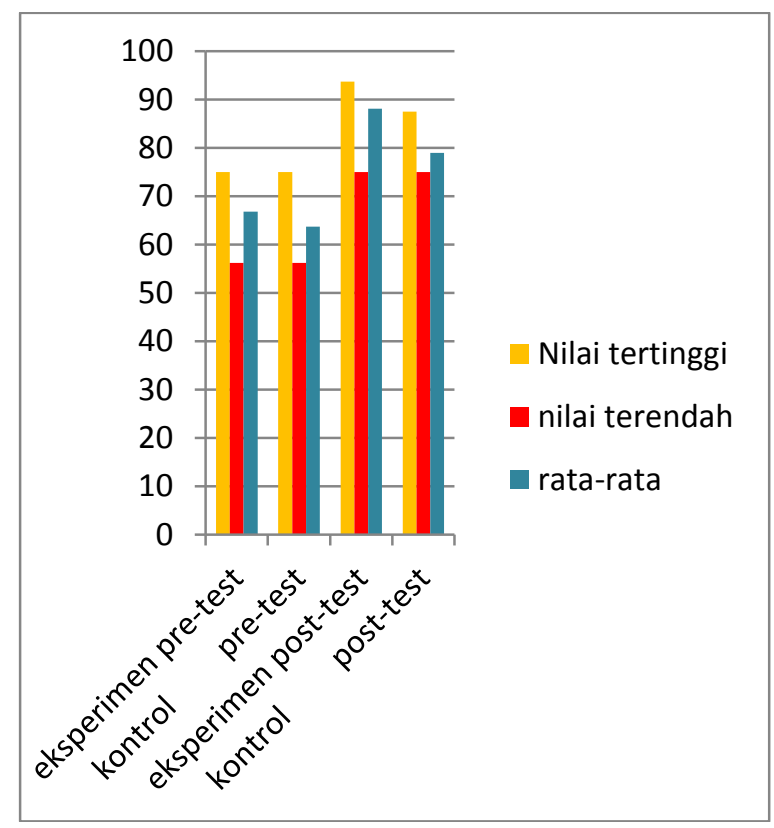

Gambar 1. Data Perbandingan Hasil Pre-test dan Posttest Kemampuan Kreativitas Anak Kelompok Eksperimen dan Kelompok Kontrol
Berdasarkan gambar 1 terlihat bahwa sebelum dilakukan post-test nilai yang didapat anak pada pre-test adalah nilai tertinggi pada kelompok eksperimen adalah 75 dan kelompok kontrol adalah 68,75 dan nilai terendah untuk kelompok ekperimen adalah 56,25 dan kontrol 56,25, nilai ratarata yang diperoleh anak adalah 66,87 untuk kelompok eksperimen dan 63,75 untuk kelompok kontrol. Setelah dilakukan post-test nilai anak meningkat pada kedua kelompok.

Perbandingan nilai terlihat anak pada kelompok eksperimen berkembang lebih besar dibandingkan dengan kelompok kontrol, yaitu nilai tertinggi yang berhasil dicapai anak pada kelompok eksperimen adalah 93,75 sedangkan kelompok kontrol adalah 87,5 dan nilai terendah yang didapat anak kelompok ekperimen adalah 75 dan kontrol 75 . Selanjutnya nilai rata-rata yang didapat oleh anak kelompok eksperimen 88,12 sedangkan kontrol 81,87. Nilai effectsize $=1,27$ bahwa bermain kulit jeruk relatif tinggi terhadap kemampuan kreativitas anak berdasarkan uji Cohen's.

Berdasarkan penjelasan di atas dapat disimpukan bahwa perkembangan kreativitas efektif dengan kegiatan bermain kulit jeruk bali dibandingkan dengan kertas warna, terlihat dari nilai pada rata-rata yang berhasil dicapai anak yaitu kelompok eksperimen 88,12 sedangkan kontrol 81,87 ,uji cohen's dengen effectsize 1,27.

\section{Pembahasan}

Berdasarkan hasil pre-test perkembangan keativitas anak pada kelompok eksperimen dan kelompok kontrol pada pre-test diperoleh angka ratarata kelompok eksperimen yaitu 66,87. Angka rata-rata kelompok kontrol yaitu 63,75 . Berdasarkan hasil analisis data yang telah dilakukan bahwa $t_{\text {hitung }}$ sebesar 1,6578 dibandingkan dengan $\alpha$ 0,05( $t_{\text {tabel }}=3,841$ ) dengan derajat kebebasan $\mathrm{dk}\left(\mathrm{N}_{1}-1\right)+\left(\mathrm{N}_{2}-\right.$ $1)=18$. Dengan demikian $t_{\text {hitung }}<t_{\text {tabel }}$ yaitu $1,6578<3,841$, maka dapat dikatakan 
bahwa hipotesis $\mathrm{H}_{a}$ ditolak $\mathrm{H}_{\mathrm{o}}$ diterima. Jadi dapat disimpulkan bahwa tidak terdapat pengaruh yang signifikan dari bermain kulit jeruk bali terhadap perkembangan kreativitas anak di Taman Kanak-kanak Kasih Ibu Pasaman Timur.

Hasil perkembangan kreativitas anak pada kelompok eksperimen dan kelompok kontrol pada post-test diperoleh angka ratarata kelompok eksperimen yaitu 88,12. Angka rata-rata kelompok kontrol yaitu 81,87 . Berdasarkan hasil analisis data yang telah dilakukan bahwa thitung sebesar 2,561 dibandingkan dengan $\alpha$ 0,05 (t $t_{\text {tabel }}=$ 2,10092) dengan derajat kebebasan $\mathrm{dk}\left(\mathrm{N}_{1^{-}}\right.$ $1)+\left(N_{2}-1\right)=18$. Dengan demikian $t_{\text {hitung }}>t_{\text {tabel }}$ yaitu 2,561 > 2,07387, maka dapat dikatakan bahwa hipotesis $\mathrm{H}_{\mathrm{a}}$ diterima atau $\mathrm{H}_{\mathrm{o}}$ ditolak. Dapat disimpulkan bahwa terdapat pengaruh yang signifikan dari bermain kulit jeruk bali dalam mengembangkan kreativitas anak di Taman Kanak-kanak Kasih Ibu Pasaman Timur.

Menurut Husna (2009: 20) menyatakan jeruk bali adalah jeruk sebesar buah melon dan berkulit tebal. Kulitnya dapat dimanfaatkan kembali untuk dibuat mobil-mobilan sederhana. Kulit jeruk tidak asing lagi untuk anak, tetapi anak tidak mengetahui kalau kulit jeruk dapat digunakan untuk bermain. Terutama dalam mengembangkan kreativitas anak, dengan bermain kulit jeruk anak dapat bekreasi sesuai dengan idenya sendiri. Menurut Rukmana (2002: 9) menyatakan salah satu limbah yang dapat diolah dalam skala industri rumah tangga adalah limbah kulit jeruk besar. Limbah kulit jeruk besar biasanya dibuang ketempat sampah atau dibuat mainan anak-anak. kulit jeruk dapat diolah menjadi produk baru.

Menurut Mulyasa ( 2012: 103) mengatakan pengembangan kreativitas anak usia dini dapat dilakukan melalui karya nyata yaitu :

\begin{abstract}
"Melalui suatu karya nyata, setiap anak akan menggunakan imajinasinya untuk membentuk suatu bangunan atau benda tertentu sesuai dengan khayalannya, bukan hanya kreativitas yang akan berkembang dengan baik, tetapi juga kemampuan kognitif anak. Ketika anak menciptakan suatu karya nyata terjadi proses internalisasi antara imajinasi dan kemampuan kreatifnya. Karya nyata anak dapat berupa suatu yang baru bagi dirinya atau merupakan inovasi dari karyakarya yang sudah ada dan setiap anak akan menunjukkan bentuk karya yang berbeda-beda sesuai dengan kemampuan dan imajinasinya."
\end{abstract}

Pendapat Rachmawati dan Euis (2010:52) menjelaskan pengembangan kreativitas pada anak melalui hasta karya ini memiliki posisi penting dalam berbagai aspek perkembangan anak, seperti :

"Dalam kegiatan hasta karya setiap
anak akan menggunakan imajinasinya
untuk membentuk suatu bangunan
atau benda tertentu sesuai
khayalanya. Setiap anak bebas
mengekspresikan kreativitasnya,
sehingga kita akan memperoleh hasil
yang berbeda antara satu anak
dengan anak lainnya. Pada dasarnya
hasil karya anak yang akan dibuat
melalui aktivitas membuat,
menyusun, atau mengkontruksi ini
akan memberikan kesempatan bagi
anak untuk menciptakan benda
buatan mereka sendiri yang belum
pernah mereka temui, ataupun
mereka membuat modifikasi dari
benda yang telah ada sebelumnya."

Berdasarkan teori diatas dapat disimpulkan bahwa pengembangan kreativitas dapat dilakukan melalui menciptakan suatu produk atau karya 
nyata. Melalui suatu karya nyata ini memberikan kesempatan pada setiap anak untuk menciptakan benda buatan sediri yang belum pernah ditemuinya. Mereka juga bisa memodifikasi sesuatu dari benda yang telah ada sebelumnya. Hal yang pernah ditekankan disini adalah bahwa setiap aktivitas anak akan membantu mereka menjadi lebih kreatif dan semangat untuk menemukan yang baru.

Pada saat peneliti mencobakan bermain menggunaan kulit jeruk bali pada kelompok eksperimen (kelas B3) di Taman Kanak-kanak Ibu Kasih Pasaman Timur, semua anak terlihat antusias dan semangat untuk mencobanya. Karena penggunaan bahan alam (kulit jeruk bali) tidak pernah digunakan sebagai bahan untuk membuat alat permainan bagi anak, karena pada saat sekarang ini banyak alat permainan yang dibuat oleh pabrik, yang dapat membuat anak menjadi kurang berinteraksi dengan temannya. Penggunaan kulit jeruk bali bisa digunakan berbagai bentuk alat permainan sesuai dengan kreasi anak yang bisa dimainkan oleh anak bersama temantemannya. Selain itu, kulit jeruk bali dapat ditemukan disekitar kita, dan juga tidak berbahaya bagi anak dan sampahnya murah terurai di lingkungan.

Sedangkan pada kelompok kontrol dengan menggunakan kertas warna, hanya sebagian anak yang bisa berkreasi. Hal ini terjadi karena guru hanya mengandalkan buku gambar dan pensil warna saat melakukan kegiatan. Selain itu disebabkan karena anak kesulitan saat menghubungkan kertas berwarna. Hal ini mengakibatkan sebagian anak yang mampu berkreasi dan berkembangn kreativitasnya dan kegiatan seperti ini membuat anak kurang semangat dalam melakukan kegiatan tersebut.

Hasil penelitian yang peneliti lakukan tentang penggunaan kulit jeruk bali dalam mengembangkan kreativitas anak terbukti bahwa kulit jeruk bali efektif dalam mengembangkan kreativitas anak, jarang anak-anak yang memainkan mainan buatan sendiri. Rata-rata, mainan anak sudah di buat oleh pabrik. Melalui kegiatan ini, anak akan dibuat kreatif dengan cara membuat mainannya sendiri, dengan menggunkan bahan yang ditemui di sekitar lingkungan tempat tinggal seperti kulit jeruk bali. Jadi, hubungan hasil penelitian yang peneliti lakukan dengan penggunaan kulit jeruk bali dalam kegiatannya ini anak membuat suatu karya nyata atau bentuk baru sesuai imajinasi dan keinginannya dengan menggunakan kulit jeruk bali.

Jadi, hasil perkembangan kreativitas anak di kelompok eksperimen lebih berpengaruh dari pada hasil perkembangan kreativitas anak di kelas kontrol, dapat dilihat dari rata-rata nilai anak kelompok eksperien yang lebih tinggi dari pada kelompok kontrol. Berdasarkan hal tersebut dapat disumpulkan bahwa terdapat perbedaan yang signifikan antara perkembangan kreativitas anak dikelompok eksperiemen dan kelompok kontrol menunjukkan bahwa bermain kulit jeruk bali berpengaruh terhadap perkembangan kreativitas anak.

\section{KESIMPULAN}

Berdasarkan hasil analisis data penelitian yang telah dilakukan, maka dapat diambil kesimpulan sebagai berikut :

Hasil penelitian yang diperoleh terdapat perbedaan hasil perkembangan kreativitas anak di Taman Kanak-kanak Kasih Ibu Pasaman Timur yang signifikan yaitu antara kelas eksperimen (B2) dan kelas kontrol (B3). Hal ini membuktikan bahwa dengan bermain kulit jeruk dapat mempengaruhi perkembangan kemampuan kreativitas pada anak, sehingga nilai ratarata yang diperoleh dari kelas eksperimen lebih tinggi $(88,25)$ dibandingkan kelas kontrol yang menggunakan kertas $(82,3)$.

Pada uji hipotesis diperoleh hasil $t_{\text {hitung }}>t$ tabel dimana 2,561> 2,10092 yang dibuktikan dengan taraf signifikan $\alpha 0,05$ dan $\mathrm{dk}=18$ ini berarti terdapat perbedaan 
yang signifikan antara hasil perkembangan kreativitas anak pada kelas eksperimen yang melakukan kegiatan bermain kulit jeruk dibandingkan dengan kelas kontrol yang melakukan kegiatan menggunakan kertas.

Pada uji Cohen's diperoleh hasil efectsize $=1,27$ dimana $\mathrm{d}=0,80$. Kesimpulan, bahwa bermain kulit jeruk terhadap perkembangan kreativitas dengan effectsize yang dinyatakan tinggi.

Berdasarkan hasil analisis data penelitian yang telah dilakukan, maka peneliti mengemukakan saran sebagai berikut : 1).Bagi Anak, Diharapkan agar kemampuan kreativitas anak dapat berkembang dengan baik melalui melukis bermain kulit jeruk bali. 2). Bagi Guru, Dalam mengembangkan kreativitas anak hendaknya guru merancang kegiatan dan menggunakan media yang bervariasi kepada anak. Guru hendaknya juga bisa memanfaatkan bahan-bahan yang lebih menarik sebagai media pembelajaran. Salah satunya bahan dari alam yang dapat digunakan sebagai media pembelajran yaitu kulit jeruk bali. 3). Bagi Kepala Sekolah, Diharapkan agar lebih peduli dalam memberikan motivasi dan arahan serta media pendidikan anak yang lebih menunjang pembelajaran di sekolah untuk mengembangkan berbagai aspek perkembangan anak khususnya perkembangan kemampuan kreativitas. 4). Bagi Peneliti Selanjutnya, Hasil penelitian ini dapat menjadi sumber bacaan / literature bagi peneliti lain untuk mengembangkan penelitian yang lama.

\section{DAFTAR PUSTAKA}

Arikunto, Suharsimi. (2010). Prosedur Penelitian Suatu Pendekatan Praktik. Jakarta: Rineka Cipta.

\footnotetext{
Husna. (2009). 100+ Permainan Tradisional Indonesia Untuk Kreativitas, Ketangkasan, Dan Keakraban. Yogyakarta: Andi
}

Mahyuddin, Nenny. (2008). Asesmen Anak Usia Dini. Padang: UNP Press.

Mulyasa. (2012). Manajemen PAUD. Bandung: PT Remaja Rosdakarya

Rachmawati,Yeni dan Euis Kurniati. (2010). Strategi Pengembangan Kreativitas Pada Anak Usia Taman KanakKanak. Jakarta : Kencana

Rukmana. (2002). Kalua Kulit Jeruk Besar. Yogyakarta : Kanisius

Sudarma, Momon. (2013). Mengembangkan Keterampilan Berpikir Kreatif. Jakarta:Rajawali Press.

Sugiono. (2014) Metode Penelitian Pendidikan Pendekatan Kuantitatif, Kualitatif, dan $R$ \& D. Bandung: Alfabeta. 